\title{
ЗАБЕЗПЕЧЕННЯ КОНКУРЕНТОСПРОМОЖНОСТІ ПРОДУКЦІЇ ВІТЧИЗНЯНИХ ПІДПРИЄМСТВ ПТАХІВНИЦТВА
}

\author{
Прокопишин Оксана Степанівна \\ кандидат економічних наук, доцент \\ Львівський національний аграрний університет (м.Дубляни, Україна) \\ ORCID: 0000-0003-2080-6178 \\ irinavit1506@gmail.com
}

Розглянуто умови забезпечення конкурентних переваг підприємств птахівництва, зокрема формування ключових компетенцій. Розкрито внутрішні та зовнішні компетенції підприємств галузі та чинники, які необхідно враховувати у процесі їх визначення. Сформульовано систему показників, за якими доцільно оцінювати конкурентоспроможність продукції птахівництва. Дослідження показують, що великі підприємства мають більші можливості для формування ключових компетенцій, а отже, є більш конкурентоспроможними. Менші підприємства більш вразливі до цінової конкуренції, а за відсутності власної торговельної марки та торговельної мережі втрачають і споживача. Натомість конкурентною перевагою малих підприємств є можливість виробництва органічної продукції.

Ключові слова: конкурентоспроможність продукції, ключові компетенції, конкурентна перевага, підприємства птахівництва, інновації.

DOI: https://doi.org/10.32845/bsnau.2019.1.5

Постановка проблеми. Високі темпи зростання споживчого попиту та низькі бар'єри входження в галузь зумовлюють привабливість ринку птахівництва. Внутрішнім ринком споживається 87,1\% виробленого м'яса птиці, а експортується лише 22,9\%, що свідчить про насиченість внутрішнього ринку птахівництва і можливість його зростання за рахунок закріплення позицій на традиційних зовнішніх ринках та освоєння нових. Перераховані чинники формують умови зростаючої конкуренції всередині галузі, а дослідження щодо забезпечення конкурентоспроможності підприємств галузі актуальні. У сучасних умовах є чимало невирішених проблем, пов'язаних із конкурентоспроможністю продукції підприємств галузі, а також безліч чинників, які передовсім впливають на формування її належного рівня.

Аналіз останніх досліджень і публікацій. Теоретичні та практичні аспекти конкуренції й конкурентоспроможності продукції підприємств вивчають Б. Бащук, В. Блонська, 3. Варналій, В. Геєць, А. Загородній, С. Клименко, Ф. Котлер, М. Портер, М. Саєнко, Р. Фатхудінов, М. Юдін та інші вітчизняні та зарубіжні вчені. У їхніх працях розглянуто питання діяльності підприємства в умовах конкуренції, напрями підвищення конкурентоспроможності підприємства і його продукції, класифікацію чинників конкурентоспроможності національної економіки, підприємств і продукції, окремі аспекти оцінки конкурентоспроможності підприємств.

Проблеми стану вітчизняного птахівництва, шляхи забезпечення якості м'яса птиці, а також значного підвищення конкурентоспроможності як на внутрішньому, так і на зовнішньому ринках, розглядали такі дослідники: Ю.В. Бондаренко, І.О. Щетиніна, В.І. Д'яченко, О.О. Катеринич, О.В. Терещенко, С.В. Руда, Н.Н. Братішко, А.М. Котік, В.О. Труфанов, В.В. Рухляда, В.П. Хвостик, Д.М. Микитюк, О.Т. Гадючко. Науковці формують свої пропозиції щодо визначення пріоритетних чинників у забезпеченні належного рівня конкурентоспроможності підприємства в сучасних умоBax.

Однак, незважаючи на наявність потужної теоретичної бази, сьогодні є чимало теоретичних та практичних завдань, що вимагають подальшого наукового дослідження.

Формулювання цілей статті. Метою дослідження $є$

визначення шляхів підвищення конкурентоспроможності продукції вітчизняного птахівництва.

Виклад основного матеріалу дослідження. Під конкурентоспроможністю продукції заведено розуміти сукупність ії̈ властивостей, що відбиває міру задоволення конкретної потреби проти репрезентованої на ринку аналогічної продукції, здатність підприємства створювати, виробляти і продавати товари та послуги, цінові й нецінові якості яких привабливіші, ніж в аналогічної продукції конкурентів. Вона визначає здатність витримувати конкуренцію на ринку, тобто мати якісь вагомі переваги над виробами інших товаровиробників. Конкурентоспроможність $€$ результатом, що фріксує наявність конкурентних переваг. Конкурентоспроможність - одна з головних складових успіху будь-якого підприємства.

Важливою умовою забезпечення конкурентних переваг підприємств, зокрема і підприємств птахівництва, $є$ формування ключових компетенцій, які є частиною моделі досягнення успіху. Компетенції - це навички, знання, технології та зв'язки, що притаманні підприємствам-конкурентам на ринку однієї галузі. Проте ключовою компетенцією $є$ те, що підприємство вміє робити краще від інших у галузі, що важко або дорого придбати чи скопіювати, є стійким у часі та не залежить від конкретних працівників і товарів, сприймається клієнтами, дає змогу отримати додатковий прибуток. Концепція ключових компетенцій базується на здатності підприємств створювати з нижчими витратами та швидше, ніж конкуренти, певні ключові компетенції, на основі яких створюються небачені раніше продукти. Джерела конкурентних переваг слід шукати у здатності керівництва компанії консолідовувати технології та виробничі навички загальнокорпоративного значення в компетенції, які наділяють окремі бізнес-одиниці потенціалом швидкої адаптації до мінливих можливостей бізнесу [4, с. 214].

Внутрішніми компетенціями підприємств галузі птахівництва є здатність створювати конкурентоспроможну продукцію, відпрацьовані та ефективні процеси управління якістю та збутом, маркетинг, планування, бюджетування, мотивація та кваліфікований персонал. До зовнішніх компетенцій належать зв'язки з постачальником і споживачами, зв'язки з органами державного управління та можливість лобіювання, зв'язки з фінансовими інститутами та інвесторами, тобто 
спроможність забезпечувати фрінансування у необхідному обсязі, у короткі терміни і за прийнятною вартістю.

У процесі визначення ключових компетенцій підприємств птахівництва необхідно врахувати такі чинники:

- ставлення споживачів до іміджу підприємства та до його продукції, яку вони повинні вважати кращою, ніж у інших виробників;

- ключові компетенції мають бути унікальними для підприємства, мати властивості, які неможливо відтворити конкурентами, відсутність підробок;

- необхідне постійне удосконалення та оновлення процесів, продукції та ключових компетенцій;

- компетенції базуються на знаннях і вміннях підприємства, тому керівники повинні удосконалювати шляхи і способи набування знань, які є потенційно потужним джерелом створення нової вартості.

Визначення конкурентоспроможності продукції пов'язане з оцінкою таких показників:

- конкретні вимоги потенційних покупців (споживачів) до пропонованого на ринку товару;

- можливі розміри та динаміку попиту на продукцію;

- розрахунковий рівень ринкової ціни товару;

- очікуваний рівень конкуренції на ринку відповідних товарів; рентів;

- визначальні параметри продукції основних конку-

- найперспективніші ринки для відповідного товару та етапи закріплення на них;

- термін окупності сукупних витрат, пов'язаних із проектуванням, продукуванням і просуванням на ринок нового товару [6, с. 52].

Більшість науковців основними чинниками конкурентоспроможності підприємства вважають ціну і якість продукції, збутову політику і рекламу. Деякі вчені додають до цього переліку й інші чинники, які чинять значний вплив на конкурентоспроможність. Основними чинниками, які формують конкурентоспроможність продукції підприємств птахівництва, за визначенням О. В. Шаніна, В. О. Лаготюк, є якість, безпечність продукції, наявність запатентованої торгової марки, ціна, витрати виробництва, особливості збуту продукції, реклама [11, с.11].
Великі підприємства мають більші можливості для формування ключових компетенцій, а отже, $є$ більш конкурентоспроможними. Продукцію птахівництва в Україні виробляють 30 спеціалізованих підприємств. Найприбутковішими серед них 2017 року були агрохолдинг «Миронівський хлібопродукт», який охоплює Вінницьку птахофабрику $(20,2 \%$ від загальної суми доходу всіх птахівничих підприємств України) та Миронівську птахофабрику $(18,5 \%)$, птахогосподарство «Червоний прапор» («Авангард») (12,4\%), Гаврилівський птахівничий комплекс («Комплекс Агромарс») (7,3\%), Старинську птахофабрику (5,8\%), «Агро-Овен» (4,9\%). Загалом шість перерахованих підприємств (20\% від наявних) 2017 року отримали $77,4 \%$ від загальної суми доходу підприємств України, які займаються птахівництвом [10].

Високий рівень доходу забезпечує великим підприємствам низку конкурентних переваг: наявність власної торговельної марки, можливість проводити агресивну комунікаційну політику за рахунок зовнішньої реклами, формування розширеної представницької та торговельної мережі, якісні маркетингові дослідження. Можливість реінвестувати прибуток та переваги спеціалізації та концентрації виробництва створюють умови для впровадження інновацій та зниження собівартості виробництва за рахунок використання інноваційних технологій, а висока фінансова стійкость та ліквідність, мобільність та адаптивність управління приваблюють інвестора. Великі підприємства є лідерами в галузі і встановлюють ціни, враховуючи затрати на виробництво підприємства (а не галузі). Менші підприємства в таких умовах $€$ більш вразливими до цінової конкуренції, а за відсутності власної торговельної марки та торговельної мережі втрачають і споживача. Загалом продукція птахівництва характерна невисоким рівнем рентабельності. У сільськогосподарських підприємствах Львівської області рівень рентабельності виробництва м'яса птиці 2017 р. становив 0,9\%, яєць 0,2\%, тоді як свинини - 10,7\% [3].

Виділяють чотири типи суб'єктів, які оцінюють конкурентоспроможність тих чи інших об'єктів: споживачі, виробники, інвестори, держава [1, с. 8]. Кожен із суб'єктів по-різному сприймає конкурентоспроможність продукції (табл. 1).

1. Матриця оцінки конкурентних переваг різними суб'єктами ринку *

\begin{tabular}{|c|c|c|c|}
\hline Суб'єкти ринку & Підприємство & $\begin{array}{r}\text { Галузь } \\
\end{array}$ & Держава \\
\hline Споживачі & $\begin{array}{l}\text { Ціна, якість, асортимент, } \\
\text { пізнаваність (наявність) торгової } \\
\text { марки, реклама, розширена торгова } \\
\text { мережа, відповідність стандартам } \\
\end{array}$ & необхідність продукції & \\
\hline Підприємство & $\begin{array}{l}\text { Привабливість виробництва } \\
\text { визначається сумою прибутку від } \\
\text { реалізації та можливостей } \\
\text { зростання попиту }\end{array}$ & $\begin{array}{l}\text { співвідношення ціни і якості продукції, } \\
\text { відповідність останньої технічним, екологічним } \\
\text { та іншим нормам і стандартам, рамкові умови } \\
\text { становища на ринку, доступність входження в } \\
\text { ринок } \\
\end{array}$ & $\begin{array}{l}\text { наявність необхідних ресурсів, їх якості } \\
\text { та доступності }\end{array}$ \\
\hline Галузь & & & $\begin{array}{l}\text { регулювання привабливості ринку цієї } \\
\text { продукції шляхом субсидій чи дотацій } \\
\text { вітчизняному виробнику, або квот і митних } \\
\text { бар'єрів до закордонних постачальників }\end{array}$ \\
\hline Інвестори & $\begin{array}{l}\text { економічне становище, фінансова } \\
\text { стійкість, можливість впровадження } \\
\text { інновацій, адаптивність управління }\end{array}$ & $\begin{array}{l}\text { есрективність вкладень, затребуваність товару } \\
\text { та рівень рентабельності продажів, } \\
\text { можливість інноваційної діяльності } \\
\end{array}$ & інвестиційний клімат \\
\hline Держава & $\begin{array}{l}\text { роль в економіці, попит на } \\
\text { продукцію і її значущість }\end{array}$ & $\begin{array}{l}\text { затребуваність та соціальна значущість товару, } \\
\text { обсяги продажів і значущість для економіки }\end{array}$ & \\
\hline
\end{tabular}

Вісник Сумського національного аграрного університету

Серія «Економіка і менеджмент», випуск 1 (79), 2019 
Ринок птахівництва розвивається досить високими темпами, що зумовлено нижчою ціною порівняно з іншими видами м'яса та дієтичністю продукту. Якщо 2017 р. в середньому в Україні на одну особу було спожито 23,6 кг м'яса птиці, то 2017 р. - 24,3 кг. Цільовим сегментом, що споживає м'ясну продукцію птахівництва, є населення середнього віку (2645 років) із середнім та вищим від середнього рівнем доходу (47,2 та 36,6\%). Виробництво м'яса птиці свійської всіма категоріями господарств України становило 2015 р. 1143,7 тис. т, а 2017 р. - 1184,7 тис. т або зросло на 3,6\% (у тому числі в сільськогосподарських підприємствах зростання становило 4,8\%). Частка м'яса птиці у виробництві м'яса всіх видів зросла з 49,2\% 2015 р. до 51,1\% 2017 р. в усіх категоріях господарств (у тому числі в сільськогосподарських підприємствах - 3 66,1 до 68,4\%) [5]. У структурі реалізації сільськогосподарських тварин на забій сільськогосподарськими підприємствами Львівської області 2018 р. частка птиці свійської становила 54,1\% (2017 р. - 51,8\%), свиней - 43,2\%
(43,9\%), великої рогатої худоби - 2,6\% (4,2\%) [3].

Ціни на продукцію птахівництва на внутрішньому ринку України на кінець 2018 р. характерні незначним розмахом: від 5 грн на яйця, та 5-9 грн на куряче фріле і на курячі тушки. Найнижча ціна на курячі тушки в Дніпропетровській області - 53,68 грн за 1 кг, а на куряче філе - у Львівській області - 51,05 грн за 1 кг. Найпривабливішим за ціновою конкурентною перевагою є ринок яєць м. Києва та ринки м'яса птиці Донецької (ціна на курячі тушки 62,59 грн за 1 кг) і Чернівецької (ціна на куряче фріле 56,41 грн за 1 кг) областей (табл. 2).

Зазвичай м'ясо птиці реалізується в сирому, охолодженому або замороженому вигляді. Надходження м'яса птиці на переробку незначне. У 2017 р. у Львівській області 43,8\% всього виробленого м'яса надійшло на переробку. Частка переробленого м'яса птиці становила тільки 0,02\% (для порівняння, переробка м'яса свиней становила 91,5\%) [3].

2. Рейтинги областей України за середньою ціною реалізації продукції птахівництва, грудень 2018 року *

\begin{tabular}{|c|c|c|c|}
\hline Вид продукції & Яйця (грн за десять штук) & Курячі тушки (грн за кг) & Куряче філе (грн за кг) \\
\hline У середньому в Україні & 27,00 & 57,83 & 53,90 \\
\hline Розмах ціни & $24,74-30,21$ & $53,68-62,59$ & $51,05-56,41$ \\
\hline Вінницька & $10\left(1^{* *}\right)$ & $4(1)$ & $6(1)$ \\
\hline Волинська & 18 & 23 & 2 \\
\hline Дніпропетровська & $5(1)$ & 25 & 22 \\
\hline Донецька & 14 & $1(1)$ & $5(1)$ \\
\hline Житомирська & 17 & $10(1)$ & $10(1)$ \\
\hline Закарпатська & 15 & $2(1)$ & $4(1)$ \\
\hline Запорізька & $2(1)$ & 17 & 21 \\
\hline Івано-Франківська & 12 & 15 & 16 \\
\hline Київська & $4(1)$ & 14 & 20 \\
\hline Кіровоградська & 24 & $8(1)$ & $9(1)$ \\
\hline Луганська & 19 & $5(1)$ & $8(1)$ \\
\hline Львівська & 20 & 24 & 25 \\
\hline Миколаївська & 16 & 18 & $12(1)$ \\
\hline Одеська & $7(1)$ & 20 & $13(1)$ \\
\hline Полтавська & 22 & $7(1)$ & $7(1)$ \\
\hline Рівненська & 21 & 21 & 19 \\
\hline Сумська & $9(1)$ & $9(1)$ & $3(1)$ \\
\hline Тернопільська & 13 & 19 & 24 \\
\hline Харківська & 25 & 22 & 18 \\
\hline Херсонська & $3(1)$ & $6(1)$ & 15 \\
\hline Хмельницька & $6(1)$ & $12(1)$ & $14(1)$ \\
\hline Черкаська & $8(1)$ & 16 & 23 \\
\hline Чернівецька & 23 & $3(1)$ & $1(1)$ \\
\hline Чернігівська & 11 & $11(1)$ & 17 \\
\hline М. Київ & $1(1)$ & 13 & $11(1)$ \\
\hline
\end{tabular}

** група з цінами вище за середні в Україні

Для забезпечення зростання конкурентоспроможності галузі необхідна глибша переробка, що дозволить розширити асортимент продукції та збільшити кількість потенційних споживачів. Для прикладу, яєчна продукція є не тільки високоякісним продуктом харчуванням, а й сировиною для парфумерної і фрармацевтичної промисловості.

Найважливішою конкурентною перевагою є зниження виробничих витрат. Нижча собівартість виробництва продукції дасть змогу здійснювати ефективну цінову політику, а підвищення якості продукції дотриманням технологічних та екологічних вимог посилить цю конкурентну перевагу. Цього можна досягти за рахунок використання племінної більш про-

дуктивної птиці та економного використання ресурсів, збалансованого раціону кормів, використання ефективнішого сучасного обладнання для утримання птиці, використання технологій безвідходного виробництва, впровадження інновацій.

У сучасних умовах глобалізації інноваційний розвиток стає визначальним чинником досягнення економічного лідерства, важливим інструментом у конкурентній боротьбі. Це зумовлено тим, що інновації є матеріальною основою підвищення ефективності виробництва, якості й конкурентоспроможності продукції, зниження витрат і $€$ найважливішою умовою економічного зростання на якісно новій основі [7, с. 26]. Такими інноваційними чинниками в птахівництві можуть бути перехід на відгодівлю птиці без антибіотиків, використання

Вісник Сумського національного аграрного університету 
безпечних натуральних кормів у процесі годівлі птиці, використання натуральних антибіотиків, як-от молоко кролів, вживання якого зменшує падіж птиці з перших днів життя. Іншим чинником можна назвати виробництво органічної продукції птахівництва. Такий метод передбачає вирощування птиці в умовах, наближених до природних.

Підприємства галузі птахівництва ффункціонують у невизначених економічних умовах. Для подолання невизначеності необхідно використовувати адаптивне управління, яке передбачає враховування структури, процесів, технології, ресурсів, положення, що необхідні для зниження невизначеності зовнішнього середовища, а також для створення значних конкурентних переваг у бізнес-середовищі функціонування підприємства, що дасть змогу уникнути значних ризиків [9, с. 36].

Важливе місце серед зазначених чинників конкурентоспроможності посідає торгова марка. На сьогодні торгова марка $€$ «уособленням знаку якості і вираженням певної марочної ідеї» [2]. Основним завданням торгової марки є підтримання високого іміджу виробника і підтвердження високої якості продукції підприємства. Споживачі більш прихильні до товарів відомих торгових марок, що й підвищує їх рівень конкурентоспроможності за рахунок брендового статусу.

Висновки. Сьогодні проблема конкурентоспроможності підприємства стоїть досить гостро. Адже в умовах ринкових відносин та загострення конкурентної боротьби лідируючі позиції займають тільки ті підприємства, які здатні до швидких змін в організації управління, до постійного оновлення виробництва, впровадження інновацій, постійного поліпшення якості та характеристик продукції чи послуг. Галузь птахівництва характерна високим рівнем конкуренції, тому для забезпечення конкурентних переваг у галузі необхідно велику увагу приділяти підвищенню ключових компетенцій підприємств для забезпечення їх конкурентоспроможності. Важливими напрямами забезпечення конкурентних переваг є фрормування цінової конкурентоспроможності за рахунок ефективного використання ресурсів, інтенсифікації виробничих процесів та впровадження інновацій. Умовами конкурентоспроможності за якістю $є$ дотримання технологічних та екологічних вимог виробничих процесів. Забезпечення задоволення потреб споживачів та розширення ринку можна досягнути глибшою переробкою продукції птахівництва, 30крема і переробкою в нехарчових цілях, розширенням асортименту та наявністю торгової марки.

Великі підприємства мають значні конкурентні переваги: наявність торгової марки, можливості для впровадження інновацій, привабливість для інвесторів. Конкурентною перевагою малих підприємств $є$ можливість виробництва органічної продукції. Зростання їх конкурентоспроможності можливе за рахунок розробки дієвого механізму державної підтримки, зокрема надання дешевих і тривалих кредитів для технічного переобладнання.

\section{Список літератури:}

1. Благун І. Коцептуальні засади формування конкурентної стратегії підприємства / І. Благун, Л. Гринів // Регіональна бізнес-економіка та управління. - 2012. - № 3(15). - С. 3-11.

2. Брендінг як складова політики підвищення конкурентоспроможності продукції [Електронний ресурс]. - Режим доступу: www.nbuv. gov.ua/ejournals/eui/2010_2/10vnmpkp.pdf / Н.М. Вишневська // Економічний журнал. - 2010. - № 2.

3. ГУСуЛО у Львівській області [Електронний ресурс]. - Режим доступу: https://www.lv.ukrstat.gov.ua

4. Кембел Д.В. Стратегічний менеджмент: підручник / Кембел Д.В.; пер.з англ. - М.: ООО « Видавництво Проспект», 2003. - 336 c.

5. Тваринництво України за 2018 рік : стат. зб. К.: Державна служба статистики України, 2019. - 166 с.

6. Позняк С.В. Конкурентні переваги і конкурентоспроможність / С.В. Позняк // Актуальні проблеми економіки. - 2007. - № 1. - С. 50-55.

7. Саранчук Г.М. Інноваційний розвиток сільського господарства як основа підвищення його конкурентоспроможності / Г.М. Саранчук // Інноваційна економіка. - 2009. - № 5. - С. 26-32.

8. Середні ціни на продукцію [Електронний ресурс]. - Режим доступу: http://www.market.avianua.com/

9. Смерічевська С.В. Конкурентоспроможність у соціально-економічному вимірі / С.В. Смерічевська // Актуальні проблеми економіки. - 2009. - № 3 (93). - С. 36-44.

10. Топ-30 птахосрабрик України [Електронний ресурс]. - Режим доступу: http://www.market.avianua.com/

11. Шанін О. В. Проблеми і чинники конкурентоспроможності продукції вітчизняних підприємств галузі птахівництва / О. В. Шанін, В. О. Лаготюк // Агросвіт. - № 4. - 2018. - С. 7-13.

Prokopyshyn 0.S., PhD, Associate Professor, Lviv National Agrarian University (Dublyany, Ukraine)

Support for competitive capacity of the products of domestic poultry enterprises

The articles is devoted to the study of competitive advantages of the enterprises of poultry industry, particularly formation of their key competences. The research considers internal and external competences of the branch enterprises, as well as factors necessary to be concerned in the process of their determination. The work sets a system of indices for appropriate assessment of the competitive capacity of poultry breeding products.

Results of the study confirm that large enterprises have better opportunities to develop key competences and thus, they are more competitive. A high level of income secures a set of competitive advantages for large enterprises, particularly a personal trademark, an opportunity to make aggressive communicative policy due to external advertising, formation of a wide representative and distributive network, appropriate marketing investigations. The opportunity to reinvest profit, as well as advantages of specialization and concentration of production supply conditions for introduction of innovations and reduction of production costs due to application of innovative technologies, whereas high financial stability and liquidity, mobility and adaptability of management attract investors. Large enterprises are leaders in the industry and set prices at the market, considering expenses for production of the enterprise (not 
the branch).

Under such conditions, smaller enterprises are more sensitive to pricing policy, and in case they have no their personal trademark and distributive network, they lose consumers. In contrast, a competitive advantage of small enterprises is in the opportunity to produce organic products. Raise of their competitive capacity is possible due to development of an efficient mechanism of state support, namely supply of cheap and long-term credits for technical re-equipment.

The important directions for support of competitive advantages suggest formation of a price competitive capacity by means of efficient use of resources, intensification of production processes, and introduction of innovations. Conditions of competitive capacity by product's quality expect conformity to technological and ecological requirements to production processes. Satisfaction of consumers' needs and expansion of the market can be achieved by deeper processing of the products of poultry breeding, in particular processing for non-food use, product-line expansion, and creation of a trademark.

Key words: competitive capacity of products, key competences, competitive advantage, enterprises of poultry industry, innovations.

Дата надходження до редакції: 08.11.2018 p. 